\title{
Allograft Thrombosis
}

National Cancer Institute

\section{Source}

National Cancer Institute. Allograft Thrombosis. NCI Thesaurus. Code C114842.

Thrombus formation within the arterial or venous system of donor tissue post transplantation. 